\title{
Optimizing the Use of Word Processing Software for Students of Madrasah Aliyah Al-Washliyah Medan
}
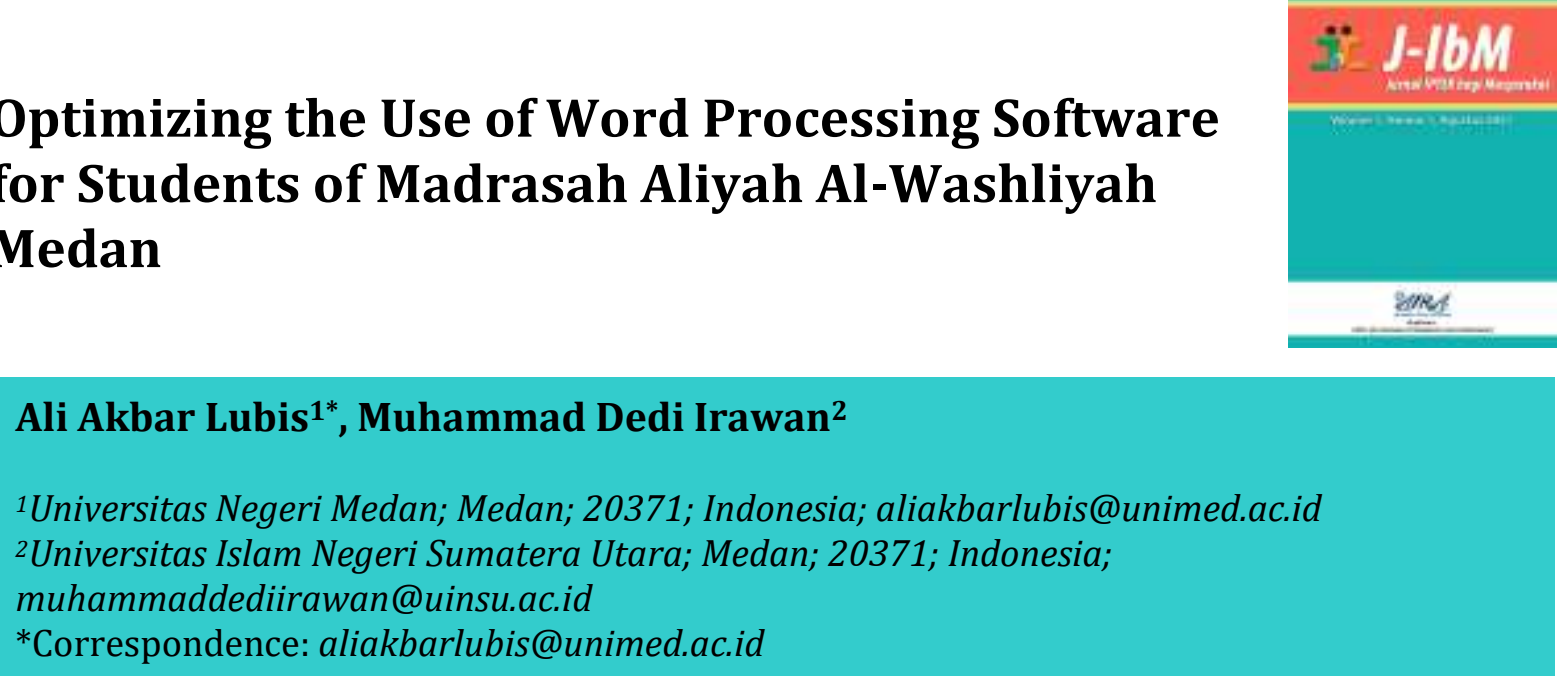

Abstract: Microsoft Office Word is one of the most widely used word processing applications in Indonesia. At Madrasah Aliyah Al-Washliyah, students have learned how to use Microsoft Office Word, but are limited to the basic features. In this community service, students and students of Madrasah Aliyah Al-Washliyah are trained to use the References feature in creating a table of contents and bibliography automatically. The purpose of this community service is to improve the ability of students in optimizing the use of Microsoft Office Word, especially in making a table of contents and bibliography.

Keywords: Optimization, Microsoft Office Word, Feature References

\section{Optimalisasi Penggunaan Software Pengolah Kata Bagi Siswa Madrasah Aliyah Al-Washliyah Medan}

Abstrak: Microsoft Office Word merupakan salah satu aplikasi pengolah kata yang paling banyak digunakan di Indonesia. Di Madrasah Aliyah Al-Washliyah, siswa dan siswi sudah pernah mempelajari penggunaan Microsoft Office Word, namun terbatas hanya pada fiturfitur dasarnya saja. Pada pengabdian kepada masyarakat ini, siswa dan siswa Madrasah Aliyah Al-Washliyah dilatih menggunakan fitur References dalam pembuatan daftar isi dan daftar pustaka secara otomatis. Tujuan dari pengabdian kepada masyarakat ini yaitu untuk meningkatkan kemampuan siswa dan siswi dalam mengoptimalisasi penggunaan Microsoft Office Word, terutama dalam pembuatan daftar isi dan daftar pustaka.

Kata Kunci: Optimalisasi, Microsoft Office Word, Fitur References

\section{Pendahuluan}

Di era digital saat ini, komputer menjadi salah satu sarana pendukung yang membantu siswa dalam kegiatan belajar. Perkembangan teknologi telah membawa perubahan besar terhadap kehidupan manusia(Irmawati, Meiriska, Novianti, \& Sartika, 2020). Para siswa dan siswi dituntut untuk dapat menggunakan aplikasi - aplikasi komputer. Penggunaan teknologi informasi dengan memanfaatkan penggunaan software 
aplikasi pengolah kata dan data yang mudah dan powerfull dengan tetap mempermudah siswa sangat penting(Sari, Fitriyani, \& Prabandari, 2020). Tak jarang guru memberikan tugas kepada siswa untuk membuat laporan dalam bentuk makalah atau karya tulis ilmiah yang dikerjakan menggunakan Microsoft Office Word.

Sejak awal tahun 2000-an, Microsoft Office sudah mendapat tempat di hati para penggunanya karena pengoperasian atau penggunaannya yang mudah untuk dipahami(Ramadhan \& Saefudin, 2021). Microsoft Office Word merupakan salah satu aplikasi pengolah data yang menyediakan berbagai fitur yang dapat digunakan untuk membuat dan memodifikasi dokumen dengan berbagai format dan gaya (Lambert \& Frye, 2015). Selain fitur dasar untuk membuat dan memodifikasi dokumen, Microsoft Office Word sudah dilengkapi dengan fitur tambahan berupa elemen grafis, melakukan koreksi gambar hingga memodifikasi tabel dan menambahkan referensi seperti kutipan dan daftar isi(Foulkes, 2020).

Menu references di Microsoft Office Word digunakan untuk membuat daftar isi, footnotes dan endnotes, kutipan dan daftar pustaka, captions, indeks, dan otoritas tabel(Microsoft, 2016). Table of Contents pada Ms Word berfungsi untuk membuat daftar halaman secara otomatis berdasarkan heading dan styles yang sudah dibuat. Citations \& Bibliography berfungsi untuk membuat daftar pustaka pada laporan skripsi tampil secara otomatis sesuai dengan kutipan pada laporan.

Madrasah Aliyah Al-Washliyah beralamat di Jl. KL. Yos Sudarso KM.6 Tg. Mulia Kecamatan Medan Deli. Di Madrasah Aliyah Al-Washliyah, siswa dan siswi sudah pernah mempelajari penggunaan Microsoft Office Word, namun terbatas hanya pada fitur-fitur dasarnya saja. Hal ini terbukti dari hasil survei yang diberikan kepada peserta pelatihan, 48 dari 50 orang peserta atau $96 \%$ menjawab belum mengetahui cara membuat daftar isi dan daftar pustaka otomatis pada Microsoft Office Word. Oleh karena itu, dilaksanakan pengabdian masyarakat dengan judul "Optimalisasi Penggunaan Microsoft Office Word pada Siswa Madrasah Aliyah Al-Washliyah Medan". Adapun tujuan dari pengabdian kepada masyarakat ini yaitu untuk meningkatkan kemampuan siswa dalam menggunakan Microsoft Office Word secara optimal, khususnya dalam pembuatan daftar isi dan daftar pustaka otomatis.

\section{Metode}

Pengabdian kepada masyarakat dengan judul "Optimalisasi Penggunaan Microsoft Office Word pada Siswa Madrasah Aliyah Al-Washliyah Medan" ini menggunakan metode Participatory Action Research (PAR). Participatory Action Research (PAR) adalah penelitian yang secara aktif melibatkan semua pihak dalam mengkaji tindakan yang sedang berlangsung(Watters, Comeau, \& Restall, 2010).

PAR berkaitan dengan penelitian penilaian diri organisasi, dalam metode ini subjek penelitian berpartisipasi secara langsung dengan peneliti (Danley \& Ellison, 1999). PAR dimaksudkan untuk melihat, mendengar, sekaligus memahami gejala sosial yang ada di masyarakat(Noviana, 2010).

Tahapan dalam PAR dibagi ke dalam delapan tahapan yang berbeda. Sesuai dengan metode Participatory Action Research (PAR), tahapan kegiatan dapat dilihat pada gambar berikut: 


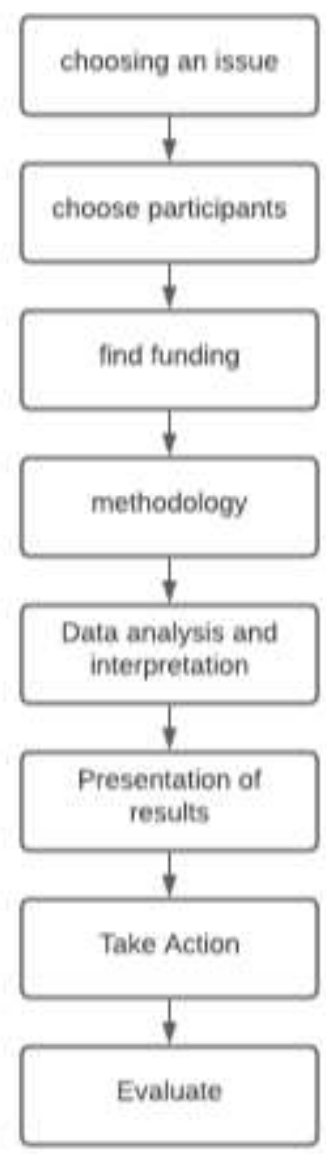

Gambar 1. Tahapan Kegiatan

1. Pemilihan isu

Pada tahap ini dilakukan identifikasi masalah terhadap objek penelitian, dalam hal ini Madrasah Aliyah Al-Washliyah Medan. Pemilihan isu ini dilakukan dengan melakukan observasi langsung di objek penelitian, serta wawancara dan survei singkat kepada pihak terkait. Selain itu, ditahap ini juga sudah ditentukan tujuan dari dilakukannya kegiatan.

2. Pemilihan peserta

Pada tahap ini ditentukan siapa saja peserta yang akan terlibat dalam kegiatan ini, dalam hal ini yaitu siswa dan siswi Madrasah Aliyah Al-Washliyah Medan sebanyak 50 orang.

3. Pencarian dana

Adapun kegiatan pengabdian kepada masyarakat ini menggunakan dana mandiri peneliti.

4. Metodologi

Metode pengumpulan data pada pengabdian kepada masyarakat ini yaitu dengan melakukan wawancara kepada Ibu Khairani, S.Pd selaku Kepala Madrasah Aliyah AlWashliyah Medan. Dalam wawancara, peneliti mendapatkan data bahwa pemanfaatan Microsoft Office Word oleh siswa dan siswi Madrasah Aliyah AlWashliyah Medan belum optimal karena siswa dan siswi hanya mengetahui fitur-fitur dasar saja. Setelah wawancara, peneliti juga melakukan survei kepada 50 orang peserta pelatihan.

5. Analisis dan Interpretasi Data 
Page 11 of 8 | J-IbM: Jurnal IPTEK bagi Masyarakat, Volume 1, Nomor 1, Agustus 2021

Data yang sudah dikumpulkan pada tahap sebelumnya diolah dan dianalisa untuk mendapatkan interpretasi data. Hasil pengumpulan dan analisis data disajikan dalam bentuk analisis deskriptif. Pada tahap ini diketahui 48 dari 50 orang peserta atau $96 \%$ menjawab belum mengetahui cara membuat daftar isi dan daftar pustaka otomatis pada Microsoft Office Word.

6. Presentasi Hasil

Dari survei yang telah dilakukan maka dapat disimpulkan bahwa penggunaan Microsoft Office Word oleh siswa dan siswi Madrasah Aliyah Al-Washliyah Medan belum optimal, sehingga dibutuhkan optimalisasi penggunaan Microsoft Office Word pada siswa Madrasah Aliyah Al-Washliyah Medan.

7. Mengambil Tindakan

Dari hasil pengumpulan dan analisis data maka diambil tindakan yaitu untuk melakukan pelatihan pembuatan daftar isi dan daftar pustaka otomatis untuk mengoptimalisasi penggunaan Microsoft Office Word pada siswa Madrasah Aliyah AlWashliyah Medan.

8. Evaluasi

Pada tahap ini dilakukan evaluasi berupa ujian kepada siswa dan siswi peserta pelatihan untuk mengetahui efektifitas dari kegiatan pelatihan yang sudah dilaksanakan.

\section{Hasil}

Pelaksanaan pengabdian kepada masyarakat yang berjudul optimalisasi penggunaan Microsoft Office Word pada siswa Madrasah Aliyah Al-Washliyah Medan ini dilaksanakan sesuai dengan masalah yang terjadi pada objek penelitian, yaitu penggunaan Microsoft Office Word oleh siswa dan siswi Madrasah Aliyah Al-Washliyah Medan belum optimal. Hal ini didasari oleh hasil survei yang diberikan kepada peserta pelatihan, 48 dari 50 orang peserta atau 96\% menjawab belum mengetahui cara membuat daftar isi dan daftar pustaka otomatis pada Microsoft Office Word.

Pelatihan ini dilaksanakan dalam waktu 1 (satu) kali tatap muka dengan durasi 3 (tiga) jam. Pelatihan ini diikuti oleh 50 orang siswa Madrasah Aliyah Al-Washliyah Medan. Adapun rincian kegiatan dapat dilihat pada tabel berikut:

Tabel 1. Waktu Pelaksanaan Pengabdian kepada Masyarakat

\begin{tabular}{|c|c|l|c|}
\hline \multicolumn{1}{|c|}{ Tanggal } & Pukul (Wib) & \multicolumn{1}{|c|}{ Kegiatan } & $\begin{array}{c}\text { Durasi } \\
\text { (menit) }\end{array}$ \\
\hline Kamis, 29 April 2021 & $13.00-13.05$ & Pembukaan & 5 \\
\cline { 2 - 4 } & $13.05-14.00$ & Pengenalan Microsoft Office Word & 55 \\
\cline { 2 - 4 } & $14.00-14.30$ & Pelatihan pembuatan daftar isi & 30 \\
\cline { 2 - 4 } & $14.30-15.00$ & $\begin{array}{l}\text { Pelatihan pembuatan daftar } \\
\text { pustaka }\end{array}$ & 30 \\
\hline & $15.00-16.00$ & Presentasi Hasil Karya Siswa & 60 \\
\hline
\end{tabular}

Adapun materi pelatihan pembuatan daftar isi dapat dilihat pada gambar di bawah ini: 
J-IbM: Jurnal IPTEK bagi Masyarakat, Volume 1, Nomor 1, Agustus 2021| Page 12 of 8

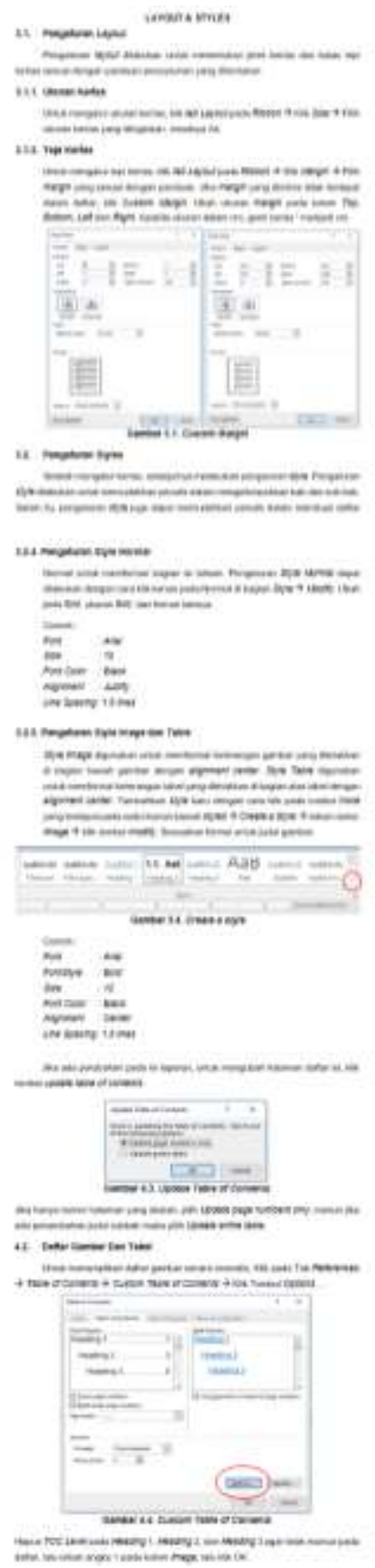

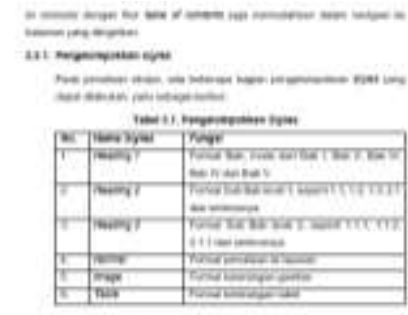
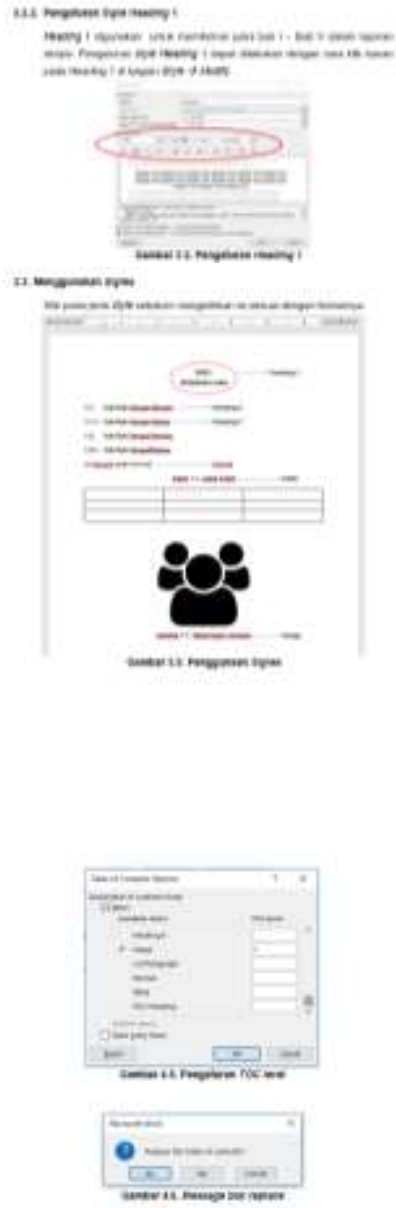

L

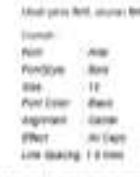

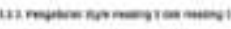

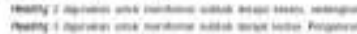

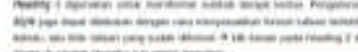
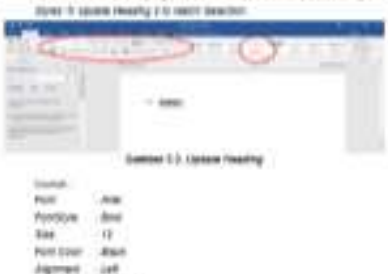

$\min _{\substack{\min \\ \min _{i=1}}}$

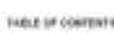

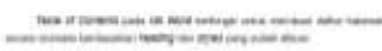

4 sente

siserion
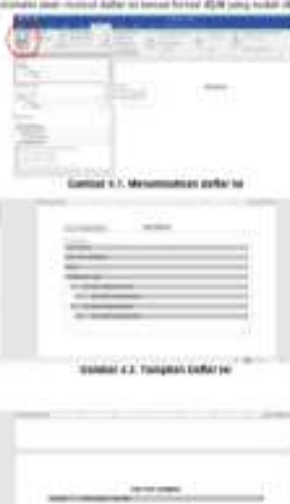

\section{Gambar 2. Materi Pelatihan Pembuatan Daftar Isi} berikut:

Adapun materi pelatihan pembuatan daftar pustaka dapat dillihat pada gambar 

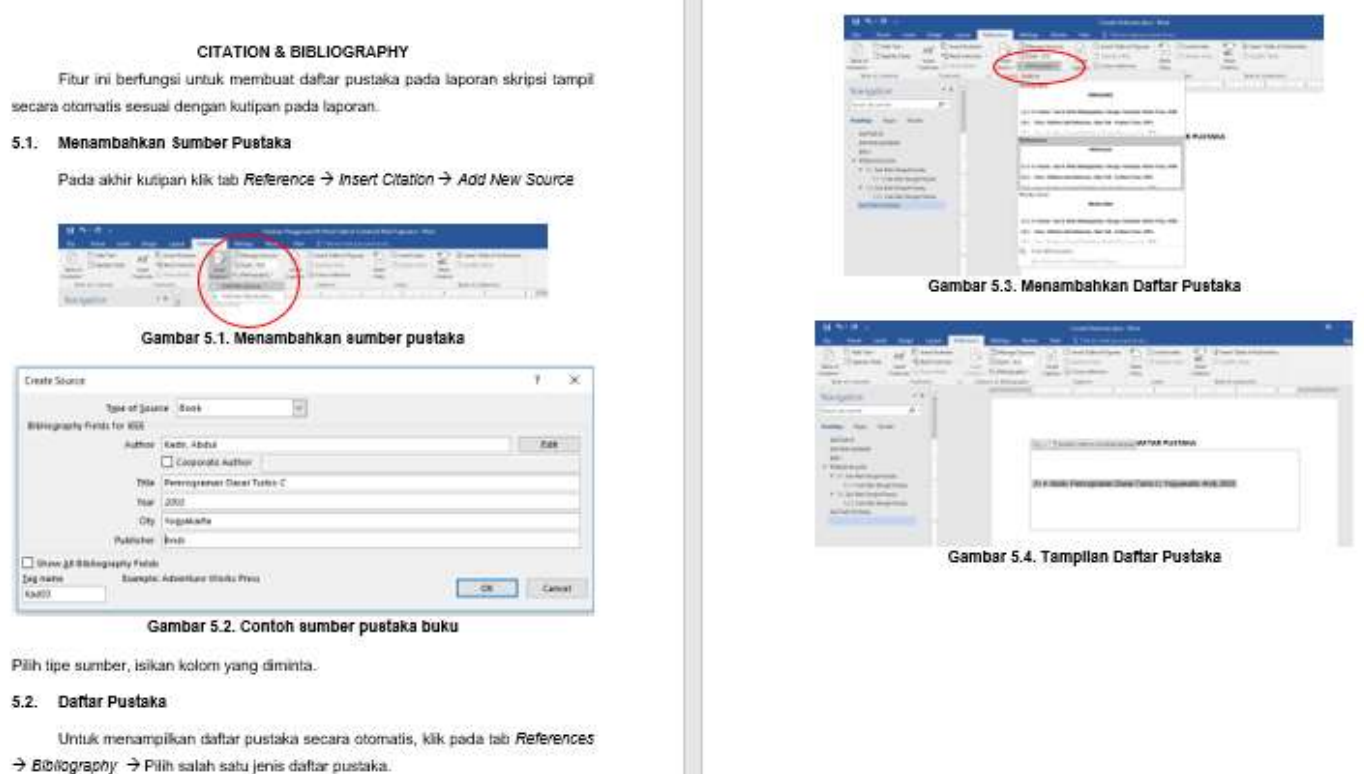

Gambar 3. Materi Pelatihan Pembuatan Daftar Pustaka

\section{Diskusi}

Sebelum kegiatan pelatihan, dilakukan survei kepada 50 orang peserta pelatihan tentang pemahaman peserta dalam penggunaan Microsoft Office Word. Setelah kegiatan pelatihan, disebarkan kuesioner kepada siswa dan siswi peserta pelatihan yang berisi 5 pertanyaan. Hasil dari kuesioner tersebut dapat dilihat pada tabel di bawah ini:

Tabel 1. Hasil Kuesioner

\begin{tabular}{|l|l|c|c|c|c|}
\hline \multirow{2}{*}{ No. } & \multicolumn{1}{|c|}{ Pertanyaan } & \multicolumn{2}{c|}{$\begin{array}{c}\text { Hasil } \\
\text { Pretest }\end{array}$} & \multicolumn{2}{c|}{$\begin{array}{c}\text { Hasil } \\
\text { Posttest }\end{array}$} \\
\cline { 3 - 6 } & \multicolumn{1}{|c|}{ Ya } & Tidak & Ya & Tidak \\
\hline 1. & $\begin{array}{l}\text { Apakah Anda sudah mengetahui fitur references } \\
\text { pada Microsoft Office Word? }\end{array}$ & $40 \%$ & $60 \%$ & $100 \%$ & - \\
\hline 2. & $\begin{array}{l}\text { Apakah Anda mengetahui cara mengatur layout } \\
\text { pada Microsoft Office Word? }\end{array}$ & $30 \%$ & $90 \%$ & $100 \%$ & - \\
\hline 3. & $\begin{array}{l}\text { Apakah Anda mengetahui cara mengatur styles } \\
\text { pada Microsoft Office Word? }\end{array}$ & $22 \%$ & $78 \%$ & $92 \%$ & $8 \%$ \\
\hline 4. & $\begin{array}{l}\text { Apakah Anda mengetahui cara membuat daftar } \\
\text { isi otomatis pada Microsoft Office Word? }\end{array}$ & $4 \%$ & $96 \%$ & $98 \%$ & $2 \%$ \\
\hline 5. & $\begin{array}{l}\text { Apakah Anda mengetahui cara membuat daftar } \\
\text { pustaka otomatis pada Microsoft Office Word? }\end{array}$ & $4 \%$ & $96 \%$ & $98 \%$ & $2 \%$ \\
\hline
\end{tabular}

Pada tabel di atas dapat dilihat perubahan yang signifikan pada pengetahuan 
peserta terhadap penggunaan fitur references pada Microsoft Office Word. Sebelum pelatihan dilakukan hanya 20 orang yang mengetahui fungsi fitur references pada Microsoft Office Word. Namun setelah pelatihan 50 dari 50 orang peserta menjawab sudah mengetahui fungsi fitur references pada Microsoft Office Word. Peningkatan yang signifikan juga terlihat pada pertanyaan tentang mengatur layout pada Microsoft Office Word. 50 dari 50 orang peserta atau $100 \%$ menjawab sudah mengetahui cara mengatur layout pada Microsoft Office Word.

Sebelum diadakan pelatihan, hanya $22 \%$ atau 11 dari 50 orang menjawab sudah mengetahui cara mengatur styles pada Microsoft Office Word. Setelah pelatihan $92 \%$ atau 46 dari 50 orang menjawab sudah mengetahui cara mengatur styles pada Microsoft Office Word. Dalam membuat daftar isi dan daftar pustaka otomatis pada Microsoft Office Word memiliki peningkatan yang sama yaitu dari $2 \%$ menjadi $98 \%$ peserta atau 49 dari 50 peserta menjawab sudah mengetahui cara membuat daftar isi dan daftar pustaka otomatis pada Microsoft Office Word.

Dari data tersebut di atas, dapat disimpulkan bahwa terjadi peningkatan pengetahuan dan kemampuan peserta sebelum dan sesudah diadakan pelatihan.

\section{Kesimpulan}

Kesimpulan yang didapat dari Program Pengabdian Kepada Masyarakat ini yaitu siswa dan siswi memahami langkah - langkah pembuatan daftar isi dan daftar pustaka otomatis pada Microsoft Office Word. Selain itu, pelatihan ini membuat penggunaan Microsoft Office Word oleh siswa dan siswi Madrasah Aliyah Al-Washliyah Medan menjadi lebih optimal

\section{Pengakuan/Acknowledgements}

Terima kasih kami ucapkan kepada Ibu Khairani, S.Pd selaku Kepala Madrasah Aliyah Al-Washliyah Medan, serta seluruh siswa dan siswi yang terlibat dalam kegiatan pengabdian kepada masyarakat dengan judul "Optimalisasi Penggunaan Microsoft Office Word pada Siswa Madrasah Aliyah Al-Washliyah Medan”.

\section{Daftar Referensi}

Danley, K. S., \& Ellison, M. L. (1999). A handbook for participatory action researchers. Psychiatry. $\quad$ Retrieved from https://escholarship.umassmed.edu/psych_cmhsr://escholarship.umassmed.edu/ psych_cmhsr/470\%0Ahttps://escholarship.umassmed.edu/psych_cmhsr

Foulkes, L. (2020). Learn Microsoft Office 2019.

Irmawati, D., Meiriska, I., Novianti, L., \& Sartika, D. (2020). Optimalisasi Penggunaan Microsoft Office Pada Staff Paud A . Rachman. SNAPTEKMAS, 137-141.

Lambert, J., \& Frye, C. (2015). Microsoft Office 2016 Step by Step. Washington: Microsoft Press.

Microsoft. (2016). Microsoft Official Academic Course. Retrieved from https://www.google.com.mx/search?q=word\&rlz=1C1GCEA_enMX757MX757\&sou rce=lnms\&tbm=isch\&sa=X\&ved=0ahUKEwjnxP7xtsPWAhWKi1QKHVPvAMwQ_AUI 
Page 15 of 8 | J-IbM: Jurnal IPTEK bagi Masyarakat, Volume 1, Nomor 1, Agustus 2021

CigB\&biw=1600\&bih=794\#imgrc=GoisG1QiJRDGoM:

Noviana, I. (2010). Participatory action research: Peningkatan kesadaran masyarakat untuk menjadikan lingkungan yang bebas narkoba (Studi kasus di Komplek Permata, Jakarta Barat. Jurnal Penelitian Dan Pengembangan Kesejahteraan Sosial, 15(3), 208218.

Ramadhan, M. A., \& Saefudin, A. (2021). Pelatihan Optimalisasi Microsoft Office Untuk Mendukung Kinerja Tenaga Pendidik di Sekolah Microsoft Office Optimization Training to Support the Performance of Educators in Schools. 5(4), 528-535.

Sari, R., Fitriyani, A., \& Prabandari, R. D. (2020). Optimalisasi Penggunaan MS. Word dan MS. Excel Pada Siswa SMP PGRI Astra Insani Bekasi. Jurnal Pengabdian Kepada Masyarakat UBJ, 3(2), 95-104. https://doi.org/10.31599/jabdimas.v3i2.184

Watters, J., Comeau, S., \& Restall, G. (2010). Participatory Action Research: An educational tool for citizen-users of community mental health services. School of Medical Rehabilitation Endowment Fund, University of Manitoba. 